\title{
IN VIVO AMELIORATIVE POTENTIAL OF CAFFEIC ACID AGAINST HEPATOTOXICITY AND NEPHROTOXICITY INDUCED BY MERCURIC CHLORIDE IN ALBINO WISTAR RATS
}

\author{
MANOGARAN MANJU, GANESAN JAGADEESAN* \\ Department of Zoology, Annamalai University, Annamalai Nagar, Chidambaram, Tamil Nadu, India. Email: jaga_zoo@yahoo.co.in
}

Received: 31 December 2018, Revised and Accepted: 14 February 2019

ABSTRACT

Objective: The current experimental study is designed to scrutinize the possible defensive effect of caffeic acid (CA) against mercury-induced hepatotoxicity in male rats.

Methods: During the treatment periods, a sub-lethal dose of $\mathrm{HgCl}_{2}(1.29 \mathrm{mg} / \mathrm{kg}$ body weight $)$ was given to rats for 15 days through oral administration and the CA was administrated for 15 days, on mercuric intoxicated rats were observed. After completing the programmed period of experimental work, the blood was drawn through a micro glass tube in the ocular region and separated the serum by centrifuge.

Results: The subsequent serum enzymes were analyzed as the alkaline phosphatase (ALP), alanine transferase (ALT), aspartate transaminase (AST), and lactate dehydrogenase (LDH). Further, the bilirubin, albumin, total cholesterol, urea, and creatinine levels were also noticed in the blood serum of both normal and treated rats. CA is one of the well-known phenolic compounds, and a strong antioxidant helps to prevent oxidative damage and reducing oxidative stress. The biological action of liver biomarker enzymes such as ALT, AST, ALP, and LDH was significantly enhanced and at the same time the drastic increased in the level of albumin was all together decreased. The level of bilirubin, total cholesterol, urea, and creatinine was significantly increased in $\mathrm{HgCl}_{2}$ intoxicated rats. When the treatment of CA on mercury intoxicated rats for 15 days (5 mg/kg body weight), in the serum enzymes (ALT, AST, ALP, and LDH) also declined to near normal level. The level of bilirubin, total cholesterol, urea, and creatinine activities was also significantly declined to near normal level when compared to mercury-treated group. The level of albumin was significantly enhanced. The CA alone treatment showed the enhanced antioxidant levels and not any alteration in the levels of biochemical parameters when compared to control.

Conclusion: These observations of the present experimental work demonstrated the detoxify effects and defensive effect of $\mathrm{CA}_{\text {against }} \mathrm{HgCl}_{2}$ toxicity in liver tissue.

Keywords: Alanine transferase, Aspartate transaminase, Alkaline phosphatase, Lactate dehydrogenase, Bilirubin, Albumin, Total cholesterol, Urea and creatinine, Mercuric chloride, Caffeic acid.

(C) 2019 The Authors. Published by Innovare Academic Sciences Pvt Ltd. This is an open access article under the CC BY license (http://creativecommons. org/licenses/by/4. 0/) DOI: http://dx.doi.org/10.22159/ajpcr.2019.v12i4.31142

\section{INTRODUCTION}

Heavy metals are known to be toxic to all type of animals including human beings [1,2]. Even at low concentration, mercury and its compounds cause deleterious effects to the animals [3]. Mercury and its compounds have been recognized as one of widespread environmental and industrial pollution [4,5]. Exposure of this heavy metal is causing numerous types of adverse health effects in animals [6]. In most manufacturing industries such as thermometers, barometers, and instruments for measuring blood pressure are responsible for releasing these heavy metals in the abiotic system $[7,8]$. Liver is the central organ to carry out all type of metabolic activities and detoxification in the animal and also carried out a different type of functions which is associated with metabolic activities and detoxification process of toxic substances [9]. The measurement of mitochondrial enzymes in the liver is considered to be a very good tool to understand the occurrence of hepatic necrosis which is associated with liver diseases $[10,11]$. In serum, the assessment and determination of liver enzymes such as alanine transferase (ALT), aspartate transaminase (AST), alkaline phosphatase (ALP), lactate dehydrogenase (LDH) and serum lipid profile, cholesterol, triacylglycerides, and lipoproteins, are providing clear picture of the liver function in an animal. It also used to evaluate the exact functional status of the liver and to detect liver cellular injury occurred in animal. If any type of alteration occurred in the enzymatic activity (biomarkers) caused drastic physiological and biochemical changes occurred in animals, and it is also considered as a marker index of hepatotoxicity [12], and it can serve as an index of liver biosynthetic capacity [13-16]. India is well-known for a plethora of medicinal plants.
The medicinal uses of many plants and its products have been reported in literature [17]. The present experimental work evaluated both the hepatoprotective and nephroprotective effect of Caffeic acid (CA) on mercuric chloride induced hepatotoxicity and nephrotoxicity in rats. In the present experimental study, hepatotoxicity and nephrotoxicity have been mediated by reactive oxygen species which is generated by administration of mercuric chloride in the rat. This type of toxicity could be managed completely by way of administration of remedial agents which is possess antioxidants [18], free radical scavengers [19], and anti-lipid peroxidation [20] activities. Administration of CA on mercury intoxicated rats was able to get complete recovery from mercuric chloride induced hepatocellular damage as evidenced in the present experimental work by prevention of any increase in serum biomarker enzymes and biochemical levels subsequent to toxin exposure and the known antioxidant, free radical scavenging, and antilipid peroxidation properties of CA might be the contributing factor for these manifestations.

\section{METHODS}

\section{Chemicals}

In the present experimental work, Mercuric chloride $\left(\mathrm{HgCl}_{2}\right), \mathrm{CA}$, and all other necessary reagents of analytical grade were used and it was purchased from HiMedia Laboratories Ltd, Mumbai, India.

\section{Animals}

Healthy male albino rats, Rattus norvegicus (180-200 g), were obtained from the Central Animal House, Department of Experimental Medicine, 
Rajah Muthiah Medical College and Hospital Annamalai University and maintained in an air condition room $\left(25 \pm 3^{\circ} \mathrm{C}\right)$ with a 12 -h light/12-h dark cycle with the hygienic condition. Feed, water, and ad libitum were provided to all the animals. The study protocols were approved by the Institutional Animal Ethics Committee of Rajah Muthiah Medical College and Hospital (Reg No: 160/1999/CPCSEA, proposal Number: 1156), Annamalai University, Annamalainagar.

\section{Experimental design}

A total of 24 animals were acclimatized in the animal cages for 15 days. The animals were randomized and divided into four groups, each group containing six rats. The toxic dosage of mercuric chloride has been obtained from our previous study as sufficient to elicit mild or moderate oxidative stress for mercuric chloride.

- Group I: Untreated control - the animals were received standard diet and clean water ad libitum and observed for 15 days.

- Group II: Mercury treatment - the animals were received $1.29 \mathrm{mg}$ of mercuric chloride/kg body weight orally every day up to 15 days.

- Group III: Mercuric chloride followed CA treatment - the animals were received mercuric chloride followed by caffeic acid (1.29 $\mathrm{mg} \mathrm{HgCl} / 2 / \mathrm{kg}$ body weight of animal for 15 days followed by caffeic acid $-5 \mathrm{mg} / \mathrm{kg}$ body wt. of animal 15 days administrated) treatment group.

- Group IV: CA alone treatment - the animals were received CA ( $5 \mathrm{mg} / \mathrm{kg}$ body weight of animal for 15 days administrated) alone treated.

\section{Sample preparation}

At the end of the experimental schedule, blood was collected through the sinoauricular punch of the animal in a dry clean test tube. And then serum was separated by centrifugation at $2000 \mathrm{rpm}$ for $10 \mathrm{~min}$. The serum samples were used for hepatic marker assay ALT AST, ALP, LDH, bilirubin, albumin and cholesterol, urea, and creatinine analysis.

\section{Biochemical marker enzymes analysis}

The ALP was estimated by King and Armstrong method [21]. The activity of AST and ALT was determined by adopting the method of King [22]. The activity of LDH was assayed by the method of King [22]. Albumins in the serum were estimated by Biuret method (Reinhold) [23]. The level of serum Bilirubin was estimated by the method of Malloy and Evelyn [24]. Total cholesterol in the plasma and tissues was estimated by the enzymatic method described by Allain [25]. Serum urea was estimated using the diagnostic kit based on the method of Fawcett and Scott [26]. Serum creatinine was estimated by the method of Bonsnes and Taussly [27].

Estimation of serum aspartate aminotransferase (AST) and alanine aminotransferase (ALT) activity

The activity of AST and ALT was determined by adopting the method of King [22]. $0.1 \mathrm{ml}$ of serum was taken in a dry clean test tube and $0.5 \mathrm{ml}$ of buffered substrate was added and placed in an incubator at $37^{\circ} \mathrm{C}$ for $10 \mathrm{~min}$. Exactly an hour later, two drops of aniline-citrate reagent and $0.5 \mathrm{ml}$ of DNPH reagent were added and kept at room temperature for $60 \mathrm{~min}$. Finally, $5.0 \mathrm{ml} 0.4 \mathrm{~N}$ sodium hydroxide was added. A set of standards also treated in the same manner and read at $520 \mathrm{~nm}$ after $10 \mathrm{~min}$. To the blank tubes, $0.1 \mathrm{ml}$ distilled water was added instead of the sample. The results were expressed as IU/L for serum.

\section{Estimation of serum ALP activity}

The ALP was estimated by the method of King and Armstrong [21]. $2.0 \mathrm{ml}$ of mixed buffered substrate was taken into clean test tubes and it was incubated for $5 \mathrm{~min}$ at $37^{\circ} \mathrm{C}$, then $0.1 \mathrm{ml}$ of serum was added in the tubes and incubated for another $15 \mathrm{~min}$. After completing the incubation period, the kinetic reaction was arrested by the addition of $0.8 \mathrm{ml}$ of $0.5 \mathrm{~N} \mathrm{NaOH}$ and then $1.2 \mathrm{ml}$ of $0.5 \mathrm{M}$ sodium carbonate was added and then thoroughly mixed. Again $1 \mathrm{ml}$ of amino antipyrine was added in the above-mixed contents and then $1.0 \mathrm{ml}$ of potassium ferricyanide was added, the color developed was read at $520 \mathrm{~nm}$ against the reagent blank in an UV-spectrophotometer. The activities of serum ALP were expressed as IU/L of serum.

\section{Estimation of LDH activity in serum}

The activity of LDH was assayed by the method of King [22]. $0.5 \mathrm{ml}$ of serum was taken in a clean, dry test tube, and $1.0 \mathrm{ml}$ of buffered substrate was added, and then the mixed content was incubated at $37^{\circ} \mathrm{C}$ for $15 \mathrm{~min}$ in an incubator. After $15 \mathrm{~min}, 0.2 \mathrm{ml}$ of coenzyme solution (NAD) was then added to the above contents and then again incubated for $15 \mathrm{~min}$. After completing the incubation period, the reaction was stopped by the addition of $1.0 \mathrm{ml}$ of 2 , 4-dinitrophenylhydrazine. The contents were incubated at $37^{\circ} \mathrm{C}$ for another $15 \mathrm{~min}$ and $5 \mathrm{ml}$ of $0.4 \mathrm{~N} \mathrm{NaOH}$ was added to the contents and mixed well. The color was developed. The intensity of the color was measured at $520 \mathrm{~nm}$ in an UV-spectrophotometer. A control was performed simultaneously as like a test, but serum was added after the addition of DNPH. The enzyme activity was expressed as IU/L for serum.

\section{Estimation of serum total bilirubin}

The level of serum bilirubin was estimated by the method of Malloy and Evelyn [24]. $0.5 \mathrm{ml}$ at serum was taken in a clean test tube and added $2 \mathrm{ml}$ of the Protein free filtrate and $0.8 \mathrm{ml}$ of distilled water and the solution was well mixed with constant rotation, and then $0.8 \mathrm{ml}$ of diacetyl monoxime solution was added. The contents were thoroughly mixed, and $0.8 \mathrm{ml}$ of arsenic sulfuric acid solution was added and mixed thoroughly and then kept in an incubator at $100^{\circ} \mathrm{C}$ for exactly $20 \mathrm{~min}$. The test tubes were allowed against a reagent gradually cool in ambient air for at least $15 \mathrm{~min}$ and then cooled in a $25^{\circ} \mathrm{C}$ water bath for at least another $15 \mathrm{~min}$. The test tubes were kept away from direct light during the heating and the cooling periods. The yellow color developed was read at $475 \mathrm{~nm}$ in an UV spectrophotometer against a reagent blank, urea nitrogen was used to construct the standard graph. The level of serum bilirubin was exposed as IU/L.

\section{Estimation of serum albumin}

Albumin in the serum was estimated by Reinhold method [23]. $0.5 \mathrm{ml}$ of sample was taken in a clean, dry test tube, and $9.5 \mathrm{ml}$ of sodium sulfite solution was added and thoroughly mixed. After mixing, $3.0 \mathrm{ml}$ of the mixture was transferred into a tube for total protein estimation to which $5.0 \mathrm{ml}$ of biuret reagent was added. To the rest of the mixture, $3.0 \mathrm{ml}$ of ether was added, stoppered, shaken well for $20 \mathrm{sec}$ and then centrifuged for $5 \mathrm{~min} .3 .0 \mathrm{ml}$ of the clear supernatant was taken for the estimation of albumin and treated with $5 \mathrm{ml}$ of biuret reagent. Simultaneously, $2.0 \mathrm{ml}$ of standard egg albumin was mixed with $1.0 \mathrm{ml}$ of water and treated with $5.0 \mathrm{ml}$ of biuret reagent. The purple color developed was read at $540 \mathrm{~nm}$ after $15 \mathrm{~min}$ using reagent blank. Values were expressed as $\mathrm{g} / \mathrm{dL}$.

\section{Estimation of total cholesterol}

The total cholesterol in the plasma and tissues was estimated by the method described by Allain et al. [25]. $0.1 \mathrm{ml}$ of serum was taken in a clean dry test tube and to this $4.9 \mathrm{ml}$ of ferric chloride-acetic acid reagent added then centrifuged at $3000 \mathrm{rpm}$ for $5 \mathrm{~min}$. After complete the centrifugation, $2.5 \mathrm{ml}$ taken in a clean test tube and to this $1.5 \mathrm{ml}$ of concentrated $\mathrm{H}_{2} \mathrm{SO}_{4}$ was added and the absorbance was read after $30 \mathrm{~min}$ at $560 \mathrm{~nm}$ in an UV spectrophotometer against a reagent blank ( $2.5 \mathrm{ml}$ of ferric chloride-acetic acid reagent and $1.5 \mathrm{ml}$ of con. $\mathrm{H}_{2} \mathrm{SO}_{4}$ ). The cholesterol concentration was expressed as $\mathrm{mg} / \mathrm{dl}$ of plasma or $\mathrm{mg} / \mathrm{g}$ of tissue.

\section{Estimation of serum urea}

Serum urea was estimated using the diagnostic kit based on the method of Fawcett and Scott [26]. $10 \mu \mathrm{L}$ of serum was taken in a clean dry test tube and $1.0 \mathrm{ml}$ of buffered enzyme was added and then thoroughly mixed well and kept at $37^{\circ} \mathrm{C}$ for $5 \mathrm{~min} .10 \mu \mathrm{L}$ of standard and $10 \mu \mathrm{L}$ distilled water (blank) were also processed simultaneously. To all the 
tubes, $1.0 \mathrm{ml}$ of color developing reagent was added and mixed well and incubates the contents for $5 \mathrm{~min}$ at $37^{\circ} \mathrm{C}$ in an incubator. After completing the incubation period, $1.0 \mathrm{ml}$ of distilled water was added and the color developed was read at $600 \mathrm{~nm}$ in an UV-spectrophotometer against a reagent blank. The results are expressed as $\mathrm{mg} / \mathrm{dl}$ of serum.

\section{Estimation of serum creatinine}

Serum creatinine was estimated by the method of Bonsnes and Taussly [27]. Diluted $1.0 \mathrm{ml}$ of $10 \%$ of serum was taken in a clean, dry test tube, and $1.0 \mathrm{ml}$ of $2 \mathrm{~N}$ sulfuric acid was added. The contents were mixed well and filtered the contents with the help of Whatman No. 1 filter paper. From this filtrate, $3.0 \mathrm{ml}$ of content was taken in a test tube and $2.0 \mathrm{ml}$ of picric acid solution and $2.0 \mathrm{ml}$ of $0.75 \mathrm{n}$ sodium hydroxide were added. The yellow color developed was read at $540 \mathrm{~nm}$ in the UV-spectrophotometer against a reagent blank. Creatinine was used to construct the standard graph. The values are expressed as $\mathrm{mg} / \mathrm{dl}$.

\section{Statistical analysis}

Values are given as mean \pm SD. for six rats in each group. The data for various biochemical parameters were analyzed using analysis of t-test, and the group means was compared by Duncan's multiple range test [28]. Values were considered statistically significant when $\mathrm{p}<0.05$ and the values sharing a common superscript did not differ significantly.

\section{RESULTS}

Table 1 shows that the level of ALT AST, ALP, LDH, and bilirubin was significantly increased in mercury intoxicated rat blood serum compared to control. On administration of CA to animals, the level of ALT AST, ALP, LDH, and bilirubin was significantly decreased near to normal level compared to mercuric chloride induced rat.

Table 2 shows that the level of cholesterol, urea, and creatinine was significantly increased in mercuric chloride induced rat blood serum compared to the control group. The CA-treated rats were cholesterol, urea, and creatinine significantly restored near normal level compared to mercuric chloride intoxicated rats. Albumin activity is a significant decreased in mercuric chloride intoxication rats. Treatment of CA orally administrated the rats; the albumin activity was significantly increased near to normal level compared to mercuric chloride intoxicated rat blood serum.

\section{DISCUSSION}

In normal condition, based on the concentration gradients between an organ and the blood compartments the enzymes were released $[10,29,30]$. The controlling mechanism of cellular enzyme release is fairly understood. In liver organ the continuous release of mitochondrial enzymes suggesting that the formation and promotion of the hepatic necrosis occurred. Abnormal secretion or release of liver marker enzymes level may provide a very good signal for liver damage or alteration in bile flow in liver organ [31]. Most of the experimental work proved that the measurement of liver enzymes activities was used as important biomarkers for the detection of hepatotoxicity nature of oxidative stress caused by toxins. Serum hepatic marker enzymes (ALT, AST, and ALP) were used to evaluate the degree of hepatotoxicity caused by toxicants. The liver is the most sensitive organ to pre-oxidative damage because it is rich in oxidizable substances. The more severe the liver damages, the higher the release of the liver enzymes [32]. The following enzymes are playing a vital role in the liver function of animals when it considered as catabolic enzymes such as alanine aminotransferase (ALT), aspartate aminotransferase (AST), and ALP $[33,34]$. ALT has played a key role to maintain the gluconeogenesis process and amino acid metabolism, particularly during stressful period [35]. In the present experimental work, the decreased level of protein content and total free amino acids is also noticed in the liver tissues of rat when treated with mercuric chloride. This result suggested that during the administration of mercury toxin exerts its toxicity effect to cause the protein degradation and utilization of amino acids to get extra energy for overcome their toxicity effect. During the process of protein catabolism occurred in the mercury intoxicated animal, ALT is play a key role to complete the kinetic reactions to get extra energy through the generating process of pyruvate and glutamate products. ALT is catalysis alanine and alpha-ketoglutarate and transfers them into respective products. Moreover, it also plays a key role in the process of glucose and amino acid of intermediate metabolism [36]. In normal condition, only a little amount of ALT release into the bloodstream, if the level of ALT activity increased in the blood suggested that the liver gets injured due to the stress or intoxication [37-39]. Therefore, ALT is considered as one of the important indexes of diagnosis of liver function in animals as well as in human beings [40]. In the present experimental study, an increased level of ALT activity was noticed in the blood circulatory system of rat when treated with mercuric chloride. The present result suggested that the increased level of ALT activity in the blood is mainly due to the cellular damages occurred in the mercury intoxicated liver. During the mercury treatment, most of the hepatocytes are damaged, and some of the liver cells are lasted its conformational structure and also getting in necrotic condition. The leakages of ALT from the cytosol of the mitochondrial compartments of the liver cells to the bloodstream are mainly due to the necrotic condition of liver cells and it also indicates that the liver cells are damaged. Most of the

Table 1: The effect of hepatic metabolic enzymes of ALT, AST, ALP, LDH, and bilirubin activity on Caffeic acid with mercuric chloride induced rat blood serum

\begin{tabular}{llllll}
\hline Groups & ALT & AST & ALP & LDH & Bilirubin \\
\hline Control & $21.62 \pm 1.65$ & $40.29 \pm 3.07$ & $85.28 \pm 2.84$ & $65.24 \pm 2.68$ & $0.98 \pm 0.07$ \\
Hgcl $_{2}$ & $42.18 \pm 3.23$ & $62.51 \pm 4.78$ & $145.25 \pm 1.68$ & $102.54 \pm 2.35$ & $1.53 \pm 0.12$ \\
Hgcl $_{2}+$ Caffeic acid & $34.83 \pm 2.65$ & $53.03 \pm 4.04$ & $108.21 \pm 2.42$ & $93.61 \pm 5.13$ & $1.02 \pm 0.08$ \\
Caffeic acid & $19.03 \pm 1.46$ & $39.14 \pm 3.12$ & $83.57 \pm 2.84$ & $68.41 \pm 2.18$ & $0.93 \pm 0.07$ \\
\hline
\end{tabular}

Each value is mean $\pm S D$ for six rats in each group. The data for various biochemical parameters were analyzed using analysis of t-test and the group means were compared by Duncan's multiple range test. Values were considered statistically significant at $\mathrm{P}<0.05$. ALT: Alanine transferase, AST: Aspartate transaminase, ALP: Alkaline phosphatase, LDH: Lactate dehydrogenase

Table 2: The changes of urea, creatinine, cholesterol, and albumin activity of Caffeic acid against mercuric chloride induced rats

\begin{tabular}{llll}
\hline Groups & Urea & Creatinine & Cholesterol \\
\hline Control & $32.17 \pm 0.32$ & $2.52 \pm 0.19$ & $142.60 \pm 2.63$ \\
$\mathrm{Hgcl}_{2}$ & $52.36 \pm 0.85$ & $4.63 \pm 0.35$ & $282.63 \pm 3.86$ \\
$\mathrm{Hgcl}_{2}+$ Caffeic acid & $45.32 \pm 0.62$ & $3.68 \pm 0.28$ & $3.5 \pm \pm 0.52$ \\
Caffeic acid & $31.84 \pm 0.82$ & $2.25 \pm 0.17$ & $5.16 \pm 0.39$ \\
\hline
\end{tabular}

Each value is mean \pm SD for six rats in each group. The data for various biochemical parameters were analyzed using analysis of $t$-test and the group means were compared by Duncan's multiple range test. Values were considered statistically significant at $\mathrm{P}<0.05$ 
experimental works proved that the occurrences of different type of liver damages are mainly depending on the combination of AST with other enzymes such as ALT in the ratio of 2:1 and it also useful to monitor the exact cause of liver disorders. In the present experimental work, the exact ratio of these enzymes was maintained in the blood of the normal untreated control rat. During the mercury treatment, both the levels of the AST and ALT enzyme activities are drastically increased in the blood stream suggested that the liver organ was damaged due to the enhancement of lipid peroxidation and also altered it ratio. An enhancement in the levels of ALT and AST activities in the blood is mainly due to necrosis in hepatic cells. Due to the necrotic condition in the liver cells, the permeability condition is also enhanced in the cell membrane resulting in the release of transaminases in the blood stream [41]. Both ALT and AST are considered as very good sensitive indicators of liver cell damages and also reflect the state of liver function [42]. Madkour et al. also observed the similar type of results in CCL4 treated rats; they suggested that the hepatocellular damage caused by drug toxicity of xenobiotics which results in the loss of functional integrity of cell membrane was due to increased levels of serum enzymes AST and ALT [43]. The elevated levels of ALT and AST indicate possible hepatotoxicity that would have resulted in the leakage of these enzymes into the bloodstream. ALP is a membrane-bound enzyme present in all internal organs such as liver and kidney. The main function of ALP enzyme is catalyzes specific chemical reactions through the hydrolysis process of a phosphate group in an organic molecule at an alkaline $\mathrm{pH}$ [44]. It also used as diagnostic tool to find out the degree of liver damages occurred in an animal when exposed to stressful condition [45]. In the normal condition of the animal, liver plays a key role to drain the fluid through the bile duct which is containing ALP and other substances. If the bile duct is damaged or blocked accumulating ALP and other substances were escaped or leakaged into the bloodstream. Naturally, the cell lining of the bile ducts in the liver is responsible for producing the ALP enzyme (Cholestatic) [46]. However, during hepatic cell damages, the accumulated ALP enzymes are released into the bloodstream (hepatocytes) along with aminotransferases rises prominently. Therefore, these biomarker enzymes are very useful to detect the liver damages or liver disease in animals by way of distinguishing the type of liver disease, either cholestatic or hepatocellular $[47,48]$ Ramadan et al. also observed similar type of results in D-GalN/LPS treated rats, they suggested due to injury in liver cells the enzymes serum transaminases, ALP, LDH leak into the bloodstream, and results in the rise of serum level. The extent of the increase in serum levels is proportional to the extent of liver damage. It was found that there was a significant increase in the serum marker enzymes (AST, ALT, ALP, and LDH) and the total bilirubin level when compared to normal control groups. In the present study, it was also found that decrease in the level of enzymes transaminases, ALT and LDH due to pre- or post-treatment of rats with propolis extract indicated repair of hepatic tissue caused by D-GalN/LPS [49]. For hepatic function serum bilirubin is considered as the index and LDH is an intracellular enzyme. Normally, LDH is widely distributed throughout the body. In tissues, the availability of LDH is found to be at a high level. The main role LDH is to utilize the glucose molecule for energy production. As a result, enhancement of LDH in the bloodstream could indicate the cellular damage occurs in a number of different tissues (skeletal or cardiac muscle, kidney, and liver). LDH isoenzyme plays a key role to involved in energy metabolism in muscle tissues, facilitating the production of ATP through glycolysis process during the oxygen demand or energy demand. During the hypoxic conditions or stressful situation or energy demand leads to stimulated the secretion of LDH as an alternate anaerobic pathway to increase ATP production hence high levels of LDH available in bloodstream [50]. Another reason for the enhancement of LDH levels may be increased may be due to the formation of cell necrosis caused by heavy metal treatment. Normally, erythrocytes have high levels of LDH; therefore, even low-level hemolysis occurred in the tissues can alter the serum activity considerably. Continuous enhancements of LDH are also observed for megaloblastic anemia, shock, renal infarction, hemolytic conditions, leukemias, and liver disease [51]. The various isoenzymes of LDH can be identified by electrophoresis, and these may also help in identifying the source of tissue damage [52]. Normally, LDH carried out the catalytic process for the conversion of lactate to pyruvate in a stressful condition. Therefore, it is considered as an important enzyme for generating energy in cells during the need of energy demand faced by the internal organs [53]. In the present experimental study, an enhanced level of LDH activity was noticed in the blood stream of rat when treated with mercuric chloride. Due to the mercury toxicity effect, the animals were faced with the energy demand to overcome the toxicity impact. The internal organs especially liver cells get damaged due to the oxidative process caused by mercury toxins. In the present study, an enhanced level of LDH activity noticed in the bloodstream is conforming the cellular damages occurred in the internal organs because the copious amount of LDH enzymes coming out from the damaged cellular organelles to enter in the bloodstream. Most of the experimental works prove that the estimation of LDH enzyme is used to evaluate tissue damage of the affected organ [54,55], and serum LDH is a biomarker of liver tissue lesions [56]. The occurrence of cell necrosis leads to increase the availability of LDH enzymes in tissue and serum [57]. Continuous elevation of LDH enzymes release in the blood is an indicator of cellular damages occurred in the internal organs. In the intoxicated animal, cell death, and disintegration of cell membrane also a causative factor for promoting the elevation of LDH in the bloodstream [58]. In the present experimental study also confirms that an enhanced level of serum LDH was occurred in rats when treated with mercuric chloride. LDH activity levels were increased in the blood which reflects the increased cell leakiness, hemolysis and cell death caused by oxidative stress promoted by mercury toxicity [59]. Bilirubins are enzymes normally it occurred at a higher concentration in cytoplasm. If hepatopathy occurred in an animal, bilirubin enzymes come into the bloodstream in conformity with the extent of liver damage. Measurement of bilirubin in the bloodstream is the conventional indicator of liver diseases or damages caused by the toxicants [60-62]. In normal condition, the measurement of bilirubin and its components in the blood reflects the liver function or hemolysis in animals [63]. During the breakdown of heme content bilirubin is formed [64]. The formation of conjugated bilirubin is directly related to the breakdown of the heme content, and it is then transported to the liver. In normal healthy condition of the animal, the level of albumin is the most abundant protein (nearly $52-60 \%$ of the total plasmatic protein content) occurred in blood plasma. It plays a key role in transporting endogenous ligands and xenobiotics. Albumin is the main and major protein content in the bloodstream, and it also synthesized by the liver organ. During the stressful condition, the production of albumin content is decreased due to the formation of hepatotoxicity in animals. The normal range of albumin occurred in the bloodstream is drastically altered by the exposure of heavy metal so that the measurement of albumin content present in the bloodstream can be used as a supplementary test for hepatic function of an animal [65]. The main role of albumin in the bloodstream is the formation of non-covalent complexes at specific binding sites, actuating in the regulation of their plasmatic concentration [66,67]. The liver functional capacity might be determined through the availability of albumin content present in the blood circulation because it is considered as a very good indicator of liver functional capacity [68]. In the present experimental study, the level of albumin content was drastically decreased in the blood of rat when it was treated with mercury poison. Cholesterol forms an integral part of cell membranes, providing unique physical properties to the membranes to facilitate cellular functions [69]. It is also the precursor of cholesterol ester, bile acids, and steroid hormones and its synthesis is primarily dependent on hepatocyte metabolism but may occur in any tissue. Cholesterol absorption is dependent on biliary secretion and the hydrolytic activity of pancreatic lipase. Despite the lack of fat hydrolysis during pancreatic insufficiency, some cholesterol absorption still occurs due to bile salt emulsification [70]. The amount of cholesterol from dietary sources and hepatic synthesis is under close homeostatic control with the rate of synthesis inversely proportional to absorption. The dietary cholesterol ester is majorly utilized in the liver and is lost in the form of bile acids, free cholesterol or its derivatives in bile [71]. Administration 
of mercury and its compounds is causes severe damages in glomerular cells. Heavy metals have been known to cause alterations of kidney function in animals [5,72-74]. Especially mercury and its compounds can cause adverse effects on the renal parameters and its function [75-87]. Evaluation of kidney functions in an animal, the parameters such as blood urea nitrogen, uric acid, and creatinine levels in the blood are act as very good indicators [78]. Most of the experimental studies suggested that increased levels of urea, nitrogen, uric acid, and creatinine concentrations in blood reflected the dysfunction of kidney in animals $[5,74,79-80]$. In natural condition, most of the heavy metals are promoting hepatotoxicity and nephrotoxicity in rat which leads to cellular damages occurred in liver and kidney cells mainly by inhibiting their antioxidant properties [81]. Liver and kidney diseases are worldwide problems, and conventional drugs used in the treatment of liver and kidney diseases are sometimes inadequate and can have serious adverse effects $[82,83]$. Hepatotoxicity and nephrotoxicity denote injury to the liver and kidney organs that are allied with diminished their functions. Number of medical plants and their formulations are being used for liver and kidney disorders in ethnomedical practices and in the traditional system of medicine in India [84]. Conventional drugs used in the treatment of liver and kidney diseases are often inadequate [85]. It is, therefore, necessary to search for supplementation/alternative drugs for the treatment of hepatic nephritic damages caused by heavy metal especially mercury and its compounds [86]. Drastic enhancement of serum hepatic-markers activity suggested the extensive liver injury induced by heavy metal through its free radical production in mercury intoxicated rat, which is causing hepatic cell damages resulting in increased leakage of cellular enzymes $[87,88]$. In the present experimental study, the elevated level of bilirubin concentration was noticed in the serum of mercuric chloride treated rats that shows the evidence of hepatic damage. Administration of CA attenuated mercuric chloride induced hepatotoxicity, as shown by the restoration of AST, ALT, ALP, and LDH activities and concentration of bilirubin to their near normal levels in mercury intoxicated rats. The present experimental result clearly indicates that CA may offer protection by stabilizing the cell membrane in hepatic disorders induced by mercuric chloride. Pari and Prasath [89] also observed a similar type of result in $\mathrm{Ni}$ intoxicated rat liver when it was treated again with CA. They are suggested that administration of CA protects the liver from $\mathrm{Ni}$-induced oxidative damage by decreasing and restoring the liver marker enzymes, lipid peroxidative markers and by increasing antioxidant cascade. The above effect of CA could be due to its antioxidant nature, which includes free radical scavenging and metal chelating properties. Thus, CA might prove beneficial in alleviating the toxic effects of Ni on liver.

\section{CONCLUSION}

During the recovery period, CA when administrated to orally with mercury intoxicated rat serum shows a decreased trend. An elevated level of both biochemical and bioenzymological functions was reached to near normal level in the mercury intoxicated rats when administrated with CA, respectively. The present experimental study suggests that the rats given CA followed with $\mathrm{HgCl}_{2}$ showed significant improvement of elevated serum biochemical and bioenzymological parameters are indicative of both kidney and liver function as compared with mercuric chloride treated group. CA followed by $\mathrm{HgCl}_{2}$ significantly promoted the health status of the animals and also rectified the tissue damages induced by toxicant. The present studies suggest that CA. Further research is needed to supporting this result.

\section{AUTHORS' CONTRIBUTIONS}

The authors would like to express their thanks to the Professor and Head, Department of Zoology (UGC-SAP Sponsored), Annamalai University for providing the infrastructure facility and support.

\section{CONFLICTS OF INTEREST}

The authors declare that they have no conflicts of interest.

\section{REFERENCES}

1. Durak D, Kalender S, Uzun FG, Demvr F, Kalender Y. Mercury chloride-induced oxidative stress in human erythrocytes and the effect of Vitamins C and E in vitro. Afr J Biotechnol 2010;9:488-95.

2. Apaydın FG, Baş H, Kalender S, Kalender Y. Subacute effects of low dose lead nitrate and mercury chloride exposure on kidney of rats. Environ Toxicol Pharmacol 2016;41:219-24.

3. García-Niño WR, Pedraza-Chaverrí J. Protective effect of curcumin against heavy metals-induced liver damage. Food Chem Toxicol 2014;69:182-201.

4. World Health Organization (WHO). Inorganic mercury. In: Environmental Health Criteria. Vol. 118. Geneva: World Health Organization; 1991. p. 1-115

5. Bharathi E, Jagadeesan G. Antioxidant potential of hesperidin and ellagic acid on renal toxicity induced by mercuric chloride in rats. Biomed Prev Nutr 2014;4:131-6.

6. Jagadeesan G, Margarat A. Amiliorative action of different solvent extractions of Tribulus terrestris (Linn.) extract on blood transaminese activities of mercuric chloride poisoned mice, Mus musculus. J Ecobiotech 2010;2:53-8

7. Drasch G, Bose O, Reilly S, Beinhoff C, Roider G, Maydl S. The Mt. Diwata study on the Philippines 1999 assessing mercury intoxication of the population by small scale gold mining. Sci Total Environ 2001;267:151-8

8. Järup L. Hazards of heavy metal contamination. Br Med Bull 2003;68:167-82

9. Parsai A, Eidi M, Sadeghipour A. Hepatoprotective effect of sage (Salvia officinalis L.) Leaves hydro-methanolic extract against Aspergillus parasiticus aflatoxin-induced liver damage in male rats. Bull Pharm Res 2014;4:129-32.

10. Schmidt E, Schmidt FW. Aspekte der enzym-diagnostik. Med Welt 1970;21:805-16.

11. Frederiks WM, Vogels IM, Fronik GM. Plasma ornithine carbamyl transferase level as an indicator of ischaemic injury of rat liver. Cell Biochem Funct 1984;2:217-20.

12. Reuben A. Hy's law. Hepatology 2004;39:574-8.

13. Johansson LE, Lindblad CA, Rastam LL, Ridderstr ${ }^{\circ} a l e ~ M$. Polymorphisms in the adiponutrin gene are associated with increased insulin secretion and obesity. Eur J Endocrinol 2008;159:577-83.

14. Ingawale DK, Mandlik SK, Naik SR. Models of hepatotoxicity and the underlying cellular, biochemical and immunological mechanism(s): A critical discussion. Environ Toxicol Pharmacol 2014;37:118-33.

15. Weston CJ, Shepherd EL, Claridge LC, Rantakari P, Curbishley SM, Tomlinson JW, et al. Vascular adhesion protein-1 promotes liver inflammation and drives hepatic fibrosis. J Clin Invest 2015;125:501-20.

16. Contreras-Zentella ML, Hernández-Muñoz R. Is liver enzyme release really associated with cell necrosis induced by oxidant stress? Oxid Med Cell Longev 2016;2016:3529149.

17. Vijayakumar M, Jagadeesan G, Bharathi E. Ameliorative potential of ferulic acid on cardiotoxixity induced by mercuric chloride. Bio Prev Nutr 2014;4:239-43.

18. Attri S, Rana SV, Vaiphei K, Sodhi CP, Katyal R, Nain RC, et al. Isoniazid-and rifampicin-induced oxidative hepatic injury — protection by N-acetylcysteine. Hum Exp Toxicol 2000;19:517-22

19. Sadanobu S, Watanabe M, Nakamura C, Tezuka M. In vitro tests of 1,3-dithia-2-thioxo-cyclopent-4-ene to evaluate the mechanisms of its hepatoprotective action. J Toxicol Sci 1999;24:375-81.

20. Lim HK, Kim HS, Choi HS, Oh S, Jang CG, Choi J, et al. Effects of acetylbergenin against D-galactosamine-induced hepatotoxicity in rats. Pharmacol Res 2000;42:471-4.

21. King EJ, Armstrong AR. Calcium, phosphorus and phosphatases. In: Practical Clinical Biochemistry. New Delhi: CBS Publishers; 1988. p. 458.

22. King J. The dehydrogenases or oxido reductase-lactate dehydrogenase. In: Practical Clinical Enzymology. London: Van D. Nostrand Co. Ltd.; 1965. p. 83-93

23. Reinhold JG. Manual determination of serum total protein albumin and globulin fractions by buiret method. In: Reiner M, editor. Standard Method of Clinical Chemistry. New York: Academic Press; 1953. p. 88.

24. Malloy HT, Evelyn KA. The determination of bilirubin with the photoelectric colorimeter. J Biol Chem 1937;119:481-90.

25. Allain S, Poon CC, Chan LS, Richmond W. Enzymatic determination of total serum chlosterol. Clin Chem 1974;20:470-5.

26. Fawcett JK, Scott JE. A rapid and pricise method for the determination of urea. J Clin Pathol 1960;13:156-9.

27. Bonsnes RW, Taussky HN. On the calorimetric determination of creatinine by the Jaffe reaction. J Biol Chem 1945;158:851-91. 
28. Duncan BD. Duncan's multiple range tests for correlated and heteroscedastic mean. Biometrics 1957;13:359-64.

29. Batt AM, Ferrari L. Manifestations of chemically induced liver damage. Clin Chem 1995;41:1882-7.

30. Dufour DR, Lott JA, Nolte FS, Gretch DR, Koff RS, Seeff LB, et al. Diagnosis and monitoring of hepatic injury. I. Performance characteristics of laboratory tests. Clin Chem 2000;46:2027-49.

31. Giannini EG, Testa R, Savarino V. Liver enzyme alteration: A guide for clinicians. CMAJ 2005; 172:367-79.

32. El-Khayat Z, Ahmed RE, Mahmoud SA, Wafaa IR, Tahany RE. Potential effects of bee honey and propolis against the toxicity of ochratoxin A in rats. Maced J Med Sci 2009;2:311-8.

33. Stojević Z, Piršljin J, Milinković-Tur S, Zdelar-Tuk M, Ljubić BB. Activitie activities of AST, ALT and GGT in clinically healthy dairy cows during lactation and in the dry period. Vet Arhiv 2005;75:67-73.

34. Śamanc H, Danijela K, Stojić V, Dragica S, Vujanac I, Prodanović R, et al. Application of the metabolic profile in the prediction and diagnosis of fatty liver in holstein cows. Acta Vet Beograd 2011;61:543-53.

35. Felig P. The glucose-alanine cycle. Metabolism 1973;22:179-207.

36. Kim WR, Flamm SL, Di Bisceglie AM, Bodenheimer HC, Public Policy Committee of the American Association for the Study of Liver Disease. Serum activity of alanine aminotransferase (ALT) as an indicator of health and disease. Hepatology 2008;47:1363-70.

37. Anderson FH, Zeng L, Roch NR, Yoshida EM. An assessment of clinical utility of serum ALT and AST in chronic hepatitis C. Hepatol Res 2000;18:63-71.

38. Puoti C, Bellis LB, Martellino F, Guarisco R, Dell-Unto O, Durola L, et al. Chronic hepatitis $\mathrm{C}$ and normal ALT levels: Treat the disease not the test. J Hepatol 2005;43:534-5.

39. Lai M, Hyatt BJ, Nasser I, Cyrry M, Fdhal NH. The clinical significant of persistently normal ALT in chronic hepatists B infection. J Hepatol 2007;47:760-7.

40. Kaplwitz N. Mechanism of liver injury. J Hepatol 2000;32:39-47.

41. Rana SV, Singh R, Verma S. Protective effects of few antioxidants on liver function in rats treated with cadmium and mercury. Indian J Exp Biol 1996;34:177-9.

42. Konan NA, Bacchi EM, Lincopan N, Varela SD, Varanda EA. Acute, subacute toxicity and genotoxic effect of a hydroethanolic extract of the cashew (Anacardium occidentale L.). J Ethnopharmacol 2007;110:30-8.

43. Madkour FF, Khalil WF, Dessouki AA. Protective effect of ethanol extract of Sargassum dentifolium (Phaeophyceae) in carbon tetrachloride-induced hepatitis in rats. Int $\mathrm{J}$ Pharm Pharm Sci 2012;4:637-41

44. Rankin SA, Christiansen A, Lee W, Banavara DS, Lopez-Hernandez A. Invited review: The application of alkaline phosphatase assays for the validation of milk product pasteurization. J Dairy Sci 2010;93:5538-51.

45. Pillai SS, Jagadeesan G. Influence of taurine on phosphatases acitivity in selected tissues of mercuric chloride into xicagted mice. J Exp Zool India 2005;8:295-300

46. Beaussier M, Wendum D, Schiffer E, Dumont S, Rey C, Lienhart A, et al. Prominent contribution of portal mesenchymal cells to liver fibrosis in ischemic and obstructive cholestatic injuries. Lab Invest 2007;87:292-303.

47. Lorenzen PC, Martin D, Clawin-Rädecker I, Barth K, Knappstein K. Activities of alkaline phosphatase, $\gamma$-glutamyltransferase and lactoperoxidase in cow, sheep and goat's milk in relation to heat treatment. Small Rumin Res 2010;89:18-23.

48. Arika WM, Nyamai DW, Osano KO, Ngugi MP, Njagi EN. Biochemical markers of in vivo hepatotoxicity. J Clin Toxicol 2016;6:297.

49. Ramadan A, Soliman G, Mahmoud SS, Nofal SM, Abdel-Rahman RF. Hepatoprotective and hepatotheraputic effects of propolis against D-galactosamine/lipopolysaccharride-induced liver damage in rats. Int J Pharm Pharm Sci 2015;7:372-8.

50. Holman RR, Paul SK, Bethel MA, Neil HA, Matthews DR. Longterm follow-up after tight control of blood pressure in Type 2 diabetes. N Engl J Med 2008;359:1565-76.

51. Joseph J, Mazza MD. Manual of Clinical Hematology. $3^{\text {rd }}$ ed. USA: Lippincott Williams and Wilkins; 2002. p. 461.

52. Bishop MJ, Everse J, Kaplan NO. Identification of lactate dehydrogenase isoenzymes by rapid kinetics. Proc Natl Acad Sci U S A 1972;69:1761-5.

53. Shahsavani D, Mohri M, Gholipour Kanani H. Determination of normal values of some blood serum enzymes in Acipenser stellatus Pallas. Fish Physiol Biochem 2010;36:39-43.

54. Anane R, Creppy EE. Lipid peroxidation as pathway of aluminium cytotoxicity in human skin fibroblast cultures: Prevention by superoxide dismutase+catalase and Vitamins E and C. Hum Exp
Toxicol 2001;20:477-81

55. Bhatti GK, Sidhu IP, Saini NK, Puar SK, Singh G, Bhatti JS. Ameliorative role of melatonin against cypermethrin induced hepatotoxicity and impaired antioxidant defense system in Wistar rats. IOSR J Environ Sci Toxicol Food Technol 2014;8:39-48.

56. Suzuki KT, Kanno S, Misawa S, Aoki Y. Copper metabolism leading to and following acute hepatitis in LEC rats. Toxicology 1995;97:81-92.

57. Turkez H, Geyikoglu F, Colak S. The protective effect of boric acid on aluminum-induced hepatotoxicity and genotoxicity in rats. Turk J Biol 2011;35:293-301.

58. Lindell SL, Hansen T, Rankin M, Danielewicz R, Belzer FO, Southard $\mathrm{JH}$, et al. Donor nutritional status-a determinant of liver preservation injury. Transplantation 1996;61:239-47.

59. Vasudevan D, Sreekumari S, Vaidyanathan K, editors. Clinical enzymology and biomarkers. In: Textbook of Biochemistry. $6^{\text {th }}$ ed. New Delhi: Jaypee Brothers; 2011. p. 146-59

60. Girish SA, Sudhir A, Avinash WG, Dorle K. Evaluation of hepatoprotective effect of amalkadi ghrita against carbon tetra chloride induced hepatic damage in rats. J Ethanopharmacol 2004;90:229-32.

61. Margarat A, Jagadeesan G. In vivo Recovery of Some Oxidative Parameters (SDH and LDH Activities) in Mercury Intoxicated Mice, Mus musculus. Madras: Proceeding, Environment and Bioethics LIFE, Loyola College; 2000. p. 280-9.

62. Rajamanikandan S, Sindhu T, Durgapriya D, Sophia D, Ragavendran P, Gopalakrishnan VK, et al. Protective effect of Mollugo nudicaulis Lam. On acute liver injury induced by perchloroethylene in experimental rats. Asian Pac J Trop Med 2012;5:862-7.

63. Limdi JK, Hyde GM. Evaluation of abnormal liver function tests. Postgrad Med J 2003;79:307-12

64. Fevery J. Bilirubin in clinical practice: A review. Liver Int 2008;28:592-605.

65. Singh A, Bhat TK, Sharma OP. Clinical biochemistry of hepatotoxicity. J Clin Toxicol 2011;S4:1

66. Xiang GH, Tong SL, Liu HZ. Study of interaction of mercuric chloride with bovine serum albumin by multi-spectroscopic method. J Fluoresc 2007; $17: 512$

67. Silva PR, Neto OC, Laurentiz AC, Junqueira OM, Fagliari JJ. Blood serum components and serum protein test of hybro-pg broilers of different ages. Rev Bras Ciên Avícola Camp 2007;9:229-32.

68. Ajiboye TO. Standardized extract of Vitex doniana sweet stalls protein oxidation, lipid peroxidation and DNA fragmention in acetaminopheninduced hepatotoxicity. $\mathrm{J}$ Ethnopharmacol 2015;164:273-82

69. Dietschy JM, Turley SD, Spady DK. Role of liver in the maintenance of cholesterol and low density lipoprotein homeostasis in different animal species, including humans. J Lipid Res 1993;34:1637-59.

70. Peretti N, Marcil V, Drouin E, Levy E. Mechanisms of lipid malabsorption in cystic fibrosis: The impact of essential fatty acids deficiency. Nutr Metab (Lond) 2005;2:11

71. Grundy SM, Denke MA. Dietary influences on serum lipids and lipoproteins. J Lipid Res 1990;31:1149-72.

72. Renugadevi J, Prabu SM. Naringenin protects against cadmium-induced oxidative renal dysfunction in rats. Toxicology 2009;256:128-34.

73. Vijayaprakash S, Langeswaran K, Kumar SG, Revathy R, Balasubramanian MP. Nephro-protective significance of kaempferol on mercuric chloride induced toxicity in Wistar albino rats. Biomed Aging Pathol 2013;3:119-24

74. Vanithasri V, Jagadeesan G. Restoration of antioxidant activity by $\mathrm{N}$-acetylcysteine and gallic acid on kidney tissue of mercuric chloride intoxicated Wistar rats. Int J Biol Pharm Res 2013a;4:302-7.

75. Agarwal R, Goel SK, Behari JR. Detoxification and antioxidant effects of curcumin in rats experimentally exposed to mercury. J Appl Toxicol 2010a;30:457-68.

76. Haibo Y, Zhaofa X, Wei L, Yu D, Bin X. The protective role of procyanidins and lycopene against mercuric chloride renal damage in rats. Biomed Environ Sci 2011;24:550-9.

77. Pal M, Ghosh M. Studies on comparative efficacy of a-linolenic acid and aeleostearic acid on prevention of organic mercury-induced oxidative stress in kidney and liver rat. Food Chem Toxicol 2012;50:1066-72.

78. Al-Attar AM, Al-Taisan WA. Preventive effects of black seed (Nigella sativa) extract on Sprague dawley rats exposed to diazinon. Aust J Basic Appl Sci 2010;4:957-68.

79. Rumbeiha WK, Fitzgerald SD, Braselton WE, Roth RA, Kaneene JB. Potentiation of mercury-induced nephrotoxicity by endotoxin in the Sprague-dawley rat. Toxicology 2000;149:75-87

80. Wang J, Yang Z, Lin L, Zhao Z, Liu Z, Liu X, et al. Protective effect of naringenin against lead-induced oxidative stress in rats. Biol Trace 
Elem Res 2012;146:354-9.

81. Samipillai SS, Jagadeesan G. Protective effect of taurine and glutathione against mercury induced toxicity in the liver tissue of rats. Int J Mod Res Rev 2013;1:7-12.

82. Arhoghro EM, Ekpo KE, Anosike EO, Ibeh GO. Effect of aqueous extract of bitter leaf (Vernonia amygdalina Del) on carbon tetrachloride (CCl4) induced liver damage in albino Wistar rats. Eur J Sci Res 2009;26:122-30.

83. Swarnalatha L, Reddy PN. Hepatoprotective activity of Sphaeranthus amaranthoides on D-galactosamine induced hepatitis in albino rats. Asian Pac J Trop Biomed 2012;2:S1900-5.

84. Kumar V, Modi PK, Saxena KK. Exploration of hepatoprotective activity of aqueous extract of Tinospora cordifolia an experimental study. Asian J Pharm Clin Res 2013;6:87-91
85. Jain A, Jain IP, Singh SP, Agarwal A. To evaluate hepatoprotective activity of roots of Cynodon dactylon an experimental study. Asian J Pharm Clin Res 2013;6:109-12.

86. Jyothi B, Lakshmi SM, Anitha K. Protective effect of Mirabilis jalapa Leaves on antitubercular drugs induced hepatotoxicity. Asian J Pharm Clin Res 2013;6:221-4.

87. Pillai SS, Jagadeesan G. Protective role of taurine on mercuric chloride induced neurotoxicity in rats. Poll Res 2006;25:353-6.

88. Navarro CM, Montilla PM, Martin A, Jimney J, Utrilla PM. Free radicals scavenger and anti hepatotoxic activity of Rosmarinus. Planta Med 1993;59:312-4.

89. Pari L, Prasath A. Efficacy of caffeic acid in preventing nickel induced oxidative damage in liver of rats. Chem Biol Interact 2008; 173:77-83. 